10.53116/pgaflr.2018.1.7

\title{
Structure of Revenues and Impact Thereof on the Rate of Indebtedness of Municipalities
}

\author{
Kristýna Řezníčková*
}

\begin{abstract}
* Kristýna Řezníčková, JUDr, PhD, Assistant Professor at the Department of Administrative Law and Financial Law, Faculty of Law, Palacky University in Olomouc, Czech Republic, since 2014. Specializes in fields of financial law, public finances and tax law. She is the author and co-autor of four books and more than twenty articles in journals and conference proceedings. (e-mail: kristyna. reznickova@upol.cz)
\end{abstract}

\begin{abstract}
In this article, the author examines in detail the structure of revenues of municipalities and the level of indebtedness thereof in particular periods. The author's assumption is that the high rate of revenues obtained by the municipalities from the state, have a negative impact on indebtedness of the municipalities. The aim of the article is to prove that there is a relation between the indebtedness of municipalities and the kinds of revenues thereof. Therefore, the hypothesis the author will try to prove or disprove in her work, reads as follows: "The sources of municipal revenues are a very important aspect that may have a substantial effect on the economic results of every municipality." The author in particular uses the method of analysis, synthesis and mostly in the second part of her work she also uses the comparative method.
\end{abstract}

Keywords: budget; revenue; subsidy; tax; indebtedness

\section{Introduction}

Recently a great emphasis has been put on the struggle against indebtedness. Total indebtedness has been rising, both at the level of states, territorial units, and its citizens. The logical consequence of this condition is the effort to prevent the debtors from getting into excessive debt. Due to the last economic crisis, conditions for all subjects were tightened. Evidence for this may be, for example the proposed amendment to the Czech National Bank Act, by which the Bank will try to set stricter conditions for the provision of mortgages. ${ }^{1}$

Even though the European Union put a special emphasis on the overall indebtedness of individual states in the beginning, now, by means of Directives, the Union has been trying to implement into national laws limits of indebtedness at lower territorial levels. Therefore, in 2017 it was implemented into the Czech legal order EU Directive 2011/85 on requirements for budgetary frameworks of the Member States that has brought in many changes and the strengthening of requirements for the composition of the budget. However, all these measures mean that the problem has been solved from the outside. This kind of solution in general will not bring the desired results and often receives a large portion of criticism from the addressees, even though it is them whom it is intended to serve in the end. 
I consider what prevention could be offered to the municipalities to help them reduce their indebtedness from the inside. A key to this change could be, at the municipal level, the larger independence of the municipalities and the larger extent of their own revenues within their budgets. The aim of this article is therefore to find out and emphasize what percentage of their own revenues the municipalities are capable of influencing, and to highlight the risks that municipalities will have to face. Considering the above stated, I have set down the following hypothesis: "Sources of municipal revenues are a very important aspect that may have a substantial effect on the economic results of every municipality." With regard to the scope of the issue, I will concentrate only on municipalities in the territory of the Czech Republic. The established facts could be valid, considering similar historic and political development, also in neighbouring countries, in particular in the states of the so-called Visegrád Four group.

In my work, I will at first use the descriptive method, in order to depict the conditions of the concerned issue, while the analytical method will be used later. Upon analysing the information from available sources, I will apply the method of synthesis on the analysed facts. By means of synthesis the analysed information is linked to logical units, out of which are deduced partial conclusions. In addition, the comparative method will be used in order to compare the found facts, so that relevant conclusions and de lege ferenda recommendations can be made.

The author has been dealing with similar issues for a long time. It is worth mentioning her publication Exclusive tax revenues of municipalities, ${ }^{2}$ in which the author tries to determine the level of fiscal autonomy of municipalities, or, for example articles The Issue of Tax Revenues of Local Councils ${ }^{3}$ and The Municipal Autonomy in the Czech Republic. ${ }^{4}$

\section{The Structure of Revenues in Municipal Budgets in the Czech Republic}

As to the structure of revenues, it is true since the early 1990s, that most revenues of municipalities in the Czech Republic (CR) are those that municipalities do not have any control of in respect of the level thereof. The largest percentage share of the budgets is subsidies from the state, subsidies from European funds, and shares of the stateadministered taxes (personal income tax, corporate tax, and value added tax, ${ }^{5}$ hereinafter jointly referred to as shared taxes). Revenues that can be influenced by the municipalities are in particular local fees, immovable property tax, and revenues from their own assets and the management thereof. The rates of revenues that can or cannot be influenced are shown in the table ${ }^{6}$ below. Revenues can be divided into "state" (revenues the level of which the municipaliy cannot influence) and "own" (revenues the level of which the municipality can influence). ${ }^{7}$ The following table displays data since 2000; I have not succeeded in finding older ones. In the 1990s when District Authorities still existed, revenues of both municipalities and districts were registered within the state budget under the same designation. After so many years, it is therefore very difficult to find sufficient sources of information, and to distinguish the revenues of municipalities from the revenues of districts. 
Table 1.

\begin{tabular}{|l|c|c|c|c|c|c|c|c|}
\hline Year & 1993 & 1994 & 1995 & 1996 & 1997 & 1998 & 1999 & 2000 \\
\hline State & $?$ & $?$ & $?$ & $?$ & $?$ & $?$ & $?$ & $70 \%$ \\
\hline Own & $?$ & $?$ & $?$ & $?$ & $?$ & $?$ & $?$ & $30 \%$ \\
\hline Year & 2001 & 2002 & 2003 & 2004 & 2005 & 2006 & 2007 & 2008 \\
\hline State & $76.9 \%$ & $77.6 \%$ & $80.7 \%$ & $80.8 \%$ & $77.9 \%$ & $78.3 \%$ & $79.5 \%$ & $79.1 \%$ \\
\hline Own & $23.1 \%$ & $22.4 \%$ & $19.3 \%$ & $19.2 \%$ & $22.1 \%$ & $21.7 \%$ & $20.5 \%$ & $20.9 \%$ \\
\hline Year & 2009 & 2010 & 2011 & 2012 & 2013 & 2014 & 2015 & 2016 \\
\hline State & $78.2 \%$ & $79.7 \%$ & $78.6 \%$ & $74.5 \%$ & $76.1 \%$ & $78.2 \%$ & $81.8 \%$ & $80.5 \%$ \\
\hline Own & $21.8 \%$ & $20.3 \%$ & $21.4 \%$ & $25.5 \%$ & $23.9 \%$ & $21.8 \%$ & $18.2 \%$ & $19.5 \%$ \\
\hline
\end{tabular}

Source: Compiled by the author.

The table clearly shows that municipalities in the CR can in fact influence only about $20 \%$ of their respective revenues. This fact negatively affects the necessity to plan municipal expenditures. Municipalities must be aware of the fact that they are reliant on the state for most of their revenues. How then can the local government draw up a balanced budget, as required by law, ${ }^{8}$ when they are not able to estimate or have control over $80 \%$ of the revenue part of their budget? The amount of finance provided to the municipalities by the state completely differs year by year. The biggest differences can be found in shared taxes, which make around $50 \%{ }^{9}$ of the overall volume of the revenues of municipalities. With regard to the fact that the state is bound by law to provide municipalities with a tax share, while those shares are expressed in percentage of the overall tax revenues, it is only logical that the volume of means provided to the municipalities must vary every year. Many variables count in this case.

One of them is the growth of the economy, which always affects tax collection. A number or factors affect the economy, such as GDP, the value of the Czech crown (exchange rate), inflation or the unemployment rate. The first big drop in the Czech economy was seen in the early 1990 s, when due to the changeover to a market economy the Czech Republic had to face many problems. Roughly, by the mid-1990s the Republic managed to improve the situation, but then came other downswings caused by changes in the exchange rate. Economic growth was renewed only after 1999. A little slowdown in the economy came in 2001-2003, and the consequences of the world financial crisis started to affect the CR in 2007. The situation still worsened, so in 2009-2011 the economy recorded a significant drop, which was followed by a GDP decrease in 2012 and 2013. Since then, an important slowdown has not yet been recorded. ${ }^{10}$

Although Table 1 does not show much correlation between that information, it can be calculated from the state final accounts. The most remarkable drop in tax revenues was recorded in 2009. Tax revenues of CZK 544 billion in 2008 dropped down to CZK 480 billion $^{11}$ in 2009 and it took the next three years to recover to the value of revenues of 2008. The municipalities definitely felt the decrease in revenue volume, without having any chance of solving the situation.

Another important factor that influences the level of tax collection is the value of tax rates. From the beginning, municipal budget revenues included personal income tax 
(DPFO) and corporate income tax (DPPO). From 1 January 2001, VAT was added. The development of the respective rates is shown in the following table.

Table 2.

\begin{tabular}{|l|l|l|l|l|l|l|l|l|}
\hline Year & 1993 & 1994 & 1995 & 1996 & 1997 & 1998 & 1999 & 2000 \\
\hline DPFO12 & 15,20, & 15,20, & 15,20, & 15,20, & 15,20, & 15,20, & 15,20, & 15,20, \\
& 25,32, & 25,32, & 25,32, & 25,32, & 25,32, & 25,32, \\
& $40.44 \%$ & $40.43 \%$ & $40.43 \%$ & $40 \%$ & $40 \%$ & $40 \%$ & $\begin{array}{l}25,32,40 \\
\%\end{array}$ & $25.32 \%$ \\
\hline DPPO13 & $45 \%$ & $42 \%$ & $41 \%$ & $39 \%$ & $39 \%$ & $35 \%$ & $35 \%$ & $31 \%$ \\
\hline Year & 2001 & 2002 & 2003 & 2004 & 2005 & 2006 & 2007 & 2008 \\
\hline DPFO14 & 15,20, & 15,20, & 15,20, & 15,20, & 15,20, & 12,19, & 12,19, & $15 \%$ \\
& $25.32 \%$ & $25.32 \%$ & $25.32 \%$ & $25.32 \%$ & $25.32 \%$ & $25.32 \%$ & $25.32 \%$ & \\
\hline DPPO15 & $31 \%$ & $31 \%$ & $28 \%$ & $24 \%$ & $26 \%$ & $24 \%$ & $24 \%$ & $21 \%$ \\
\hline VAT & 22 and & 22 and & 22 and & 19 and & 19 and & 19 and & 19 and & 19 and \\
& $5 \%$ & $5 \%$ & $5 \%$ & $5 \%$ & $5 \%$ & $5 \%$ & $5 \%$ & $9 \%$ \\
\hline Year & 2009 & 2010 & 2011 & 2012 & 2013 & 2014 & 2015 & 2016 \\
\hline DPFO16 & $15 \%$ & $15 \%$ & $15 \%$ & $15 \%$ & $15 \%$ & $15 \%$ & $15 \%$ & $15 \%$ \\
\hline DPPO17 & $20 \%$ & $19 \%$ & $19 \%$ & $19 \%$ & $19 \%$ & $19 \%$ & $19 \%$ & $19 \%$ \\
\hline VAT & 19 and & 20 and & 20 and & 20 and & 21 and & 21 and & 21,15 & 21,15 \\
& $9 \%$ & $10 \%$ & $10 \%$ & $14 \%$ & $15 \%$ & $15 \%$ & and $10 \%$ & and $10 \%$ \\
\hline
\end{tabular}

Source: Compiled by the author.

The last important issue that is closely connected to tax rates are Acts determining percentual rates of shares from tax revenues, which belong to municipal budgets. Allocation of revenues to the state and to the municipalities is determined from the early 90 s by the Act on budgetary rules of the Czech Republic. ${ }^{18}$ The revenues of municipalities were regulated by Section $₫ 23$. At that time, state-allocated taxes were only personal income tax and corporate income tax. On 1 January 2001, the Act on budgetary allocation of taxes came into effect, ${ }^{19}$ which significantly changed the rules. ${ }^{20}$ The development of tax shares that belonged to the budgets of municipalities is shown in the table below.

Table 3.

\begin{tabular}{|l|c|c|c|c|c|c|c|c|}
\hline Year & 1993 & 1994 & 1995 & 1996 & 1997 & 1998 & 1999 & 2000 \\
\hline DPFO $^{21}$ & $100 \%^{22}$ & $100 \%^{23}$ & $100 \%^{24}$ & $100 \%^{25}$ & $100 \%^{26}$ & $100 \%^{27}$ & $100 \%^{28}$ & $100 \%^{29}$ \\
\hline DPPO $^{30}$ & 0 & 0 & 0 & $20 \%$ & $20 \%$ & $20 \%$ & $20 \%$ & $20 \%$ \\
\hline Year & 2001 & 2002 & 2003 & 2004 & 2005 & 2006 & 2007 & 2008 \\
\hline DPFO $^{31}$ & $20.59 \%$ & $20.59 \%$ & $20.59 \%$ & $20.59 \%$ & $20.59 \%$ & $20.59 \%$ & $20.59 \%$ & $21.4 \%^{32}$ \\
\hline DPPO & $20.59 \%$ & $20.59 \%$ & $20.59 \%$ & $20.59 \%$ & $20.59 \%$ & $20.59 \%$ & $20.59 \%$ & $21.4 \%$ \\
\hline VAT & $20.59 \%$ & $20.59 \%$ & $20.59 \%$ & $20.59 \%$ & $20.59 \%$ & $20.59 \%$ & $20.59 \%$ & $21.4 \%$ \\
\hline
\end{tabular}




\begin{tabular}{|l|c|c|c|c|c|c|c|c|}
\hline Year & 2009 & 2010 & 2011 & 2012 & 2013 & 2014 & 2015 & 2016 \\
\hline DPFO $^{33}$ & $21.4 \%$ & $21.4 \%$ & $21.4 \%$ & $21.4 \%$ & $23.58 \%^{34}$ & $23.58 \%^{35}$ & $23.58 \%{ }^{36}$ & $23.58 \%$ \\
\hline DPPO $^{37}$ & $21.4 \%$ & $21.4 \%$ & $21.4 \%$ & $21.4 \%$ & $23.58 \%$ & $23.58 \%$ & $23.58 \%$ & $23.58 \%$ \\
\hline VAT & $21.4 \%$ & $21.4 \%$ & $21.4 \%$ & $19.93 \%$ & $20.83 \%$ & $20.83 \%$ & $20.83 \%$ & $20.83 \%$ \\
\hline
\end{tabular}

Source: Compiled by the author.

Data from Tables 2 and 3 can be compared to data from Table 1. The growth of the share of state revenues up to $1 \%$ a year may be rather a consequence of the growth in the economy enabling the increased collection of particular taxes. The first substantial increase of the state revenues share is seen between 2000 and 2001. It was caused by the inclusion of VAT into the shared taxes, when starting from 2001 the municipalities received a share of the VAT in amounting to $20.59 \%$. The reason for the next, though not so high increase of state revenues as compared to their own revenues in 2003 cannot be seen from the tables. It was caused by the dissolution of the districts, when powers thereof were devolved to the municipalities, and the state started to provide new subsidies to the municipalities as remuneration for the execution of those devolved powers. Further, the table shows an obvious decrease in state revenues in 2005 . The reason was a change in the funding of school education; previously the subsidies for funding school education were sent to the municipalities, but since 2005 they have been directly sent to the schools. ${ }^{38}$

Between 2007 and 2008 there was a decrease of revenues obtained by the municipalities from the state, though the tax share of the municipalities increased in all shared taxes. This phenomenon was caused by the financial crisis, and by a reduction in the income tax rates. A small increase in 2010 was probably caused by the growth of VAT rates. Even though tax rates did not decrease until 2012, the amount of revenues obtained by the municipalities from the state decreased compared to their own revenues. The reason for this was the impact of the economic crisis. The receding economic crisis and a decreased share from the VAT received by the municipalities then caused a relatively large downswing in the revenues received by the municipalities from the state in 2012. The VAT share received by the municipalities was cut mainly because the VAT rates were increased, but the legislator evidently failed to properly estimate and take into account the consequences of the crisis. The state thus caused considerable trouble in the municipal budgets. ${ }^{39}$ It was probably also for this reason that the state again increased the share of VAT for the municipalities in the year after. Along with the growth in tax rates, that step brought in a visible increase in the proportion of revenues received by the municipalities from the state and its own revenues. Thanks to the growth in the economy, the share of the state revenues received by the municipalities from the state in comparison with the share of own revenues in the following years kept increasing. The reason for a decrease in 2016 of the proportion of revenues received by the municipalities from the state and their own revenues was a reduction in the volume of subsidies provided from European funds. ${ }^{40}$ 


\section{Development of Debts of Municipalities Since 1990 to the Present}

With the establishment of the Czechoslovak Federative Republic, ${ }^{41}$ self-government slowly started to be renewed at the territorial level. That tendency continued also in the newly established Czech Republic.42 Among the most important provisions was Article 101 of the Constitution of the Czech Republic that enshrined the right of municipalities to their own property, and management and administration of their own budget. ${ }^{43}$ However, rather high demands were placed on the municipalities from the very beginning. Even though they were not indebted in the early 1990s, the conditions slowly changed. Provazníková states that a major part of expenditures was due to capital expenditures. Furthermore, they were expenditures that would not bring any real profit to the municipality in the future. Therefore, projects already carried out would not contribute in the future to pay off the debts caused by those projects. That is why the indebtedness of municipalities rapidly grew in the 1990s. ${ }^{44}$ The course of the growth of indebtedness is shown in the table below. It presents the level of overall debt of all municipalities in the Czech Republic in billion Czech crowns from 1993 to 2016. ${ }^{45}$ Concerning 2017, the Ministry of Finance has not published any data yet.

Table 4.

\begin{tabular}{|l|c|c|c|c|c|c|c|c|}
\hline Year & 1993 & 1994 & 1995 & 1996 & 1997 & 1998 & 1999 & 2000 \\
\hline Debt & 3.4 & 14.3 & 20.3 & 28.3 & 34.4 & 39 & 40 & 41 \\
\hline Year & 2001 & 2002 & 2003 & 2004 & 2005 & 2006 & 2007 & 2008 \\
\hline Debt & 48.3 & 55.8 & 70.4 & 74.8 & 79 & 80.9 & 79.2 & 80.1 \\
\hline Year & 2009 & 2010 & 2011 & 2012 & 2013 & 2014 & 2015 & 2016 \\
\hline Debt & 80.6 & 83.3 & 82.4 & 90 & 92.2 & 88.9 & 86.9 & 71.9 \\
\hline
\end{tabular}

Source: Compiled by the author.

From the stated data, about $50 \%$ of the indebtedness falls on the biggest Czech cities - Prague, Brno, Pilsen, and Ostrava. It is noteworthy that indebtedness applies to only about $50 \%$ of the Czech municipalities which is around 3,100 municipalities. The other municipalities manage to run without debts. The Ministry of Finance also states that the indebtedness of a municipality increases with the growth in its population.

The table shows that Czech municipalities over recent years have succeeded in redeeming their debts and decreasing their indebtedness. This is in accordance with the current trend over the past years, where individual states actively endeavour to reduce their respective debts after the world financial crisis, and the European Union also forces the states to do so.

Another tremendous risk concerning indebtedness is in the hidden use of EU funds. These subsidies are often several times higher than the total amount of the revenues of the municipality. In the case where the municipality breaches budgetary discipline ${ }^{46}$ in connection with the funds, it will have to return the subsidy, which may throw the 
municipality into financial turmoil and lead it to becoming debt ridden. This, however, would be a topic for a separate article.

Czech municipalities continue to succeed at redeeming their debts mainly thanks to the positive balance of their respective budgets that they have reached in recent years. Shared taxes, revenues of which have recently grown, contributed significantly to the current situation and today they constitute, as I have already noted, about $50 \%$ of the overall revenues of the municipalities. However, the question is what the next financial crisis would do to the indebtedness of the municipalities. Considering the above stated facts, I am convinced that when the next downswing of economy comes, the municipalities will start getting into debt again. It is only a matter of time. At the moment when $50 \%$ of revenues of a particular unit have a variable level and furthermore that unit cannot flexibly respond to that outage by replenishment from other sources, the unit is forced to get into debt. In my opinion, the municipalities have no other way out. This is not the best of prospects when economists forecast the coming of another financial crisis.

\section{Conclusion}

The increase of the share of the municipalities in tax revenues is a trend in the Czech Republic over the last years. This is the way how the state increases the revenues of the municipalities in accordance with their own requirements, in order to improve the financial situation. In my opinion, it is not a good step forward.

The hazard potential of this kind of revenues has become evident several times, when lower tax income occurred due to a decline in the economy or a decrease in tax rates. Logically, this caused a lower volume of means that the state paid out to the municipalities as their share of tax income. Lastly the economic crisis significantly affected the Czech Republic in 2009-2011. The aftermath thereof was no way catastrophic, however it does not mean that something worse may not happen over the next few years. Currently another problem is on the agenda at the municipal level, connected with the share in tax income. It concerns the amendment prepared by the Ministry of Finance that should decrease overall taxation of a certain kind of taxable entities, ${ }^{47}$ i.e. employees, and from 1 January 2019 to repeal so-called super-gross wages. $^{48}$ Since income tax, which will be affected by the amendment, is a significant source of revenue for municipal budgets, the Union of Towns and Municipalities of the Czech Republic immediately objected to the amendment. If the amendment to the Act is approved, it will deprive municipal budgets of about CZK 5.3 billion.

As I have already noted, municipalities are not able to flexibly respond to such an outage. They can influence about $20 \%$ of their respective revenues, and the possibilities to increase their share within this $20 \%$ are rather limited.

In addition, the municipalities are under pressure due to the rules set by the implemented Directive 2011/85/EU on requirements for budgetary frameworks of the Member States. It has been implemented into the Czech legal order as the Act on the rules of budgetary responsibility ${ }^{49}$ and as an associated act that amended ${ }^{50}$ over dozens of the legal regulations. These new duties, where the state defines for the municipalities the level of the highest possible indebtedness, also impose new sanctions as well. Pursuant to 
Section 17, the municipality is obligated, on the balance sheet date, to keep its debt below $60 \%$ of its average revenues received over the last four budgetary years. If the municipality exceeds the limit, it is obligated to cut the budget down in the following calendar year by at least $5 \%$. If it fails to do so, the state may suspend a transfer to the municipality of its share in shared tax income. ${ }^{51}$

As expected, the Union of Towns and Municipalities objected to the provision. It raised the objection that there has been a breach of the constitutional right to administer their own property and their own budget, which is the expression of the right to selfgovernment of every municipality. However, the objections remain unheard and the provision in law is valid. Thus, the municipality may easily get into serious problems that it will not be able to solve, as the state does not provide the municipality with sufficient options to gain its revenues independently of the state.

Thus, it is more than obvious that the legislator should consider in the future an extension of the municipal competences as it concerns different kinds of revenues. It has been suggested that municipalities be given an option to introduce new municipal fees, such as advertising fees, or to enable municipalities to determine a surcharge on taxes, as it is practiced in several Nordic countries..$^{52}$

Regarding the above stated, I dare say that the objective of the work has been reached and the hypothesis "Sources of municipal revenues are a very important aspect that may have a substantial effect on the economic results of every municipality" has been proven. 


\section{References}

1 Vladan Gallistl, Zárodky krizí vznikají v nejlepší době [The emergence of crises emerges in the best times], ČNB, www.cnb.cz/cs/verejnost/pro_media/clanky_rozhovory/media_2018/cl_18_180424_mora_e15. html (accessed 24 April 2018).

2 Kristýna Ǩezníčková, Výlučné daňové př́ijmy obcí [Exclusive tax revenues of municipalities], 230 (Olomouc, Iuridicum Olomoucense, 2016).

3 Kristýna Řezníčková, The Issue of Tax Revenues of Local Councils, 333-342, in Pavel Smolen (ed.), Selected Issues in Taxation and Tax Authorities in Central Europe (Lublin, Wydawnictwo KUL, 2016).

4 Kristýna Müllerová, The Municipal Autonomy in the Czech Republic, 325-337, in Petr Mrkývka (ed.) System of Financial Law: General Part: Conference Proceedings (Brno, Masaryk University, Faculty of Law, 2015).

5 Since 2017, tax from gambling has been added to shared taxes.

6 Information source: Own calculations are based on data from the Ministry of Finance of CR, and Kristýna Řezníčková, Výlučné daňové př́ijmy obcí [Exclusive tax revenues of municipalities], 82 (Olomouc, Iuridicum Olomoucense, 2016).

7 More on the issue of distinction of state and own revenues see Kristýna Řezníčková, Výlučné daňové př́jmy obcí [Exclusive tax revenues of municipalities] (Olomouc, Iuridicum Olomoucense, 2016).

8 Section 4 para 4 of Act No. 250/2000 Sb., on budgeting rules of territorial budgets, as amended.

9 Kristýna Řezníčková, Výlučné daňové př́ijmy obcí [Exclusive tax revenues of municipalities], 81 (Olomouc, Iuridicum Olomoucense, 2016).

10 Česká národní banka [Czech National Bank], www.historie.cnb.cz/cs/menova_politika/prurezova_temata_ menova_politika/1_ekonomicky_vyvoj_na_uzemi_ceske_republiky.html (accessed 24 April 2018).

11 Source: Ministry of Finance of CR.

12 Personal income tax.

13 Corporate income tax.

14 Personal income tax.

15 Corporate income tax.

16 Personal income tax.

17 Corporate income tax.

18 Act No. 576/1990 Sb., on rules of management of budgetary means of the Czech Republic and of the municipalities in the Czech Republic (Budgetary rules of the Czech Republic), as amended.

19 Act No. 243/2000 Sb., on budgetary allocation of revenues from taxes to territorial self-governing units and to some state funds (Act of budgetary allocation of taxes).

20 Explanatory memorandum to Act No. 243/2000 Sb., on budgetary allocation of taxes.

21 Personal income tax.

22 Total revenues from income tax of natural persons having residency in the territory of the municipality, $+40 \%$ of revenues from income tax on dependent activities and from fringe benefits, paid by the payer in the territory of the municipality.

23 See also note no. 22.

24 See also note no. 22.

25 Total revenues from advance income tax of natural persons having residency in the territory of the municipality, $+10 \%$ of revenues from income tax on dependent activities and from fringe benefits, paid by the payer in the territory of the municipality.

26 See also note no. 25.

27 See also note no. 25.

28 See also note no. 25.

29 See also note no. 25.

30 Corporate income tax. 
31 In addition, it applies for the whole line that the municipalities are entitled to $30 \%$ from revenues from advance income tax of natural persons, having residency in the territory of the municipality.

32 In that year so-called super-gross wages were introduced, which increased the real taxation of employees.

33 Personal income tax. In addition, it applies for the whole line that the municipalities are entitled to $30 \%$ from revenues from advance income tax of natural persons, having residency in the territory of the municipality.

34 Excluding fringe benefits, paid by the employer, where the value $22.87 \%$ applies.

35 See also note no. 34 .

36 See also note no. 34 .

37 Corporate income tax.

38 State final balance statement for 2005, Ministry of Finance, www.mfcr.cz/assets/cs/media/Statni-zaverecnyucet_2005_F-Hospodareni-rozpoctu-uzemnich-samospravnych-celku-za-rok-2005.pdf (accessed 24 April 2018).

39 Final economic statement of territorial self-government for 2012, Deník veřejné správy, www.dvs.cz/ clanek.asp?id=6608210l (accessed 24 April 2018).

40 Ministry of Finance CR, www.mfcr.cz/cs/verejny-sektor/statni-rozpocet/plneni-statniho-rozpoctu/2016/ statni-zaverecny-ucet-za-rok-2016-31478 (accessed 5 May 2018).

41 On 29 March 1990, by Constitutional Act No. 81/1990 Sb., on the change of the name of Czechoslovak Socialist Republic.

42 The Czech Republic was established on 1 January 1993.

43 Article 101 para. 3 of Constitutional Act No. 1/1993 Sb., Constitution of the Czech Republic.

44 Romana Provazníková, Olga Sedláčková, Financování měst, obcí a regionů: teorie a praxe [Financing cities, municipalities and regions: theory and practice], 196 (2nd amended edition, Prague, Grada, 2009).

45 Source of data contained in the tables: Deník veřejné správy [Journal of Public Administration], www.dvs. cz/clanek.asp?id=6432000 (accessed 25 April 2018) and Ministry of Finance CR, www.mfcr.cz/cs/ verejny-sektor/uzemni-rozpocty/zadluzenost-uzemnich-rozpoctu/2016/zadluzenost-uzemnich-rozpoctuv-roce-201-30092 (accessed 24 April 2018).

46 See in Michal Koziel, Breach of Budgetary Discipline as a Direct Consequence of the Breach of Conditions in the Management of the EU Funds, in Eva Kovářová, Lukáš Melecký, Michaela Staníčková (eds.), Proceedings of the 3rd International Conference on European Integration 2016 (Ostrava, VŠB-Technical University of Ostrava, 2016).

47 For further reading on the topic see Zdenka Papoušková, Vybrané aspekty pojmu daňový subject [Selected aspects of the term tax entity], 197-209, in Zdenka Papoušková, Michael Kohajda et al., Aktuálni otázky finančního práva ve stredoevropském prostoru (Olomouc, Iuridicum Olomucense, o. p. p., 2013) or Zdenka Papoušková, Daňové subjekty ve světle nové právní úpravy [Tax entities in the light of new legislation], 7-15, in Zdenka Papoušková et al., Vybrané instituty správy dani po zmèně právní úpravy $v \check{C} R$ a na Slovensku (Olomouc, Univerzita Palackého v Olomouci, 2012).

48 Municipalities will lose 5.3 billion due to tax allowances of the state. Union of Towns and Municipalities of the Czech Republic, www.smocr.cz/cz/tiskovy-servis/tiskove-zpravy/obce-prijdou-o-5-3-miliardvlivem-danovych-ulev-statu.aspx? referrerID=94 (accessed 25 April 2018).

49 Act No. 23/2017 Sb., on the rules of budgetary responsibility.

50 Act No. 24/2017 Sb., amending certain laws in connection with the adoption of budgetary responsibility regulations.

51 More on the new rules of budgetary responsibility: Michal Koziel, New Rules of Budgetary Responsibility and Their Impact on Public Finances, 223, in Ivana Pařízková, Eva Tomášková (eds.), Interaction of law and economics 2017: conference proceedings. Publications of Masaryk University, theoretical series, edition Scientia, File No. 604. (Brno, Masaryk University, 2017).

52 Paweł Swianiewicz, Finanse lokalne, teoria i praktyka [Local finance, theory and practice], 47 (Warsaw, Municipium, 2004). 